\title{
ПОЛУЧЕНИЕ И ИССЛЕДОВАНИЕ МНОГОФУНКЦИОНАЛЬНОГО МАГНИТНОГО СОРБЦИОННОГО МАТЕРИАЛА С МЕЗОПОРИСТОЙ ОБОЛОЧКОЙ
}

Киселева М.С., Кубракова И.В.

ФГБУН Институт геохимии и аналитической химии им. В.И. Вернадского РАН,

Москва, Россия

Mariya_Kiseleva90@mail.ru

DOI: 10.26902/ASFE-11_109

Разработан подход к созданию магнитных многофункциональных сорбционных материалов со структурой «ядро - многослойная оболочка» $\left(\mathrm{Fe}_{3} \mathrm{O}_{4} @\right.$ ТЭОС@ЦТАБ@ТЭОС+МПТЭОС), получаемых ковалентной и/или нековалентной иммобилизацией модифицирующих реагентов на поверхности наноразмерного носителя. Сорбенты такого типа сохраняют магнитные свойства носителя, устойчивы в водных средах различного состава и пригодны для одновременного или последовательного концентрирования и количественного элюирования компонентов неорганической и органической природы. Магнитные свойства сорбента обеспечивают значительное сокращение времени операций, связанных с концентрированием, за счет быстрого отделения сорбента путем магнитной сепарации.

Получение сорбентов основано на синтезе наноразмерного магнетита $\mathrm{Fe}_{3} \mathrm{O}_{4}$ и модифицировании его поверхности под действием микроволнового излучения. В этих условиях время получения мезопористых материалов сокращается на порядок. Избирательность сорбента по отношению к органическим компонентам (на примере фенола, 4-нонилфенола, 2,4-динитрофенола) и ионам тяжелых металлов (на примере $\mathrm{Cd}^{2+}, \mathrm{Pb}^{2+}, \mathrm{Hg}^{2+}$, $\mathrm{Cu}^{2+}, \mathrm{Zn}^{2+}$ ) достигалась за счет последовательной функционализации поверхности магнетита бромидом цетилтриметиламмония (ЦТАБ), обеспечивающим взаимодействие с органическими соединениями, и серосодержащими кремнийорганическими полимерами (ТЭОС+МПТЭОС), обусловливающими сорбционные свойства оболочки магнетита по отношению к ионам тяжелых металлов. Таким образом, реализована возможность использования одного сорбционного материала для извлечения различных по своей природе аналитов [1].

Синтезированные материалы детально исследованы физико-химическими методами; изучены их сорбционные свойства в статических условиях (влияние $\mathrm{pH}$, времени контакта фаз, природы элюента, V : m, солевого фона); оптимизированы условия извлечения аналитов различной природы при их содержании в растворе на уровне мкг/л. Показана перспективность применения полученного материала для определения экотоксикантов в природных водах инструментальными методами.

\section{Список литературы}

1. Киселева М.С., Пряжников Д.В., Кубракова И.В. Магнитный сорбент с мезопористой оболочкой для одновременного концентрирования экотоксикантов различной природы // Журн. аналит. химии. 2018. Т. 73. № 1 . С. $14-21$. 